Morris, T.H. (2018) 'Vocational education of young adults in England: a systemic analysis of teaching-learning transactions that facilitate self-directed learning', Journal of Vocational Education \& Training, 70 (4), pp. 619-643.

This is an Accepted Manuscript of an article published by Taylor \& Francis Group in Journal of Vocational Education \& Training on 16/4/18 available online:

https://doi.org/10.1080/13636820.2018.1463280

\title{
ResearchSPAce
}

\author{
http://researchspace.bathspa.ac.uk/
}

This pre-published version is made available in accordance with publisher policies.

Please cite only the published version using the reference above.

Your access and use of this document is based on your acceptance of the ResearchSPAce Metadata and Data Policies, as well as applicable law:https://researchspace.bathspa.ac.uk/policies.html

Unless you accept the terms of these Policies in full, you do not have permission to download this document.

This cover sheet may not be removed from the document.

Please scroll down to view the document. 
This is an author's accepted manuscript for an article published in the Journal of Vocational Education \& Training. Warning that there may be some small differences when compared to the final published article in Journal of Vocational Education \& Training by Taylor \& Francis. Copyright to the final published article belongs to Taylor \& Francis. This is the author's manuscript only and therefore page numbers in this version are different from the published version. 


\title{
Vocational education of young adults in England: A systemic analysis of teaching - learning transactions that facilitate self-directed learning
}

\begin{abstract}
Fostering the skills necessary for self-directed learning is an important endeavour of vocational education and training in many contexts internationally. However, there is a distinct lack of studies that investigate the extent to which facilitation of self-directed learning is present within vocational education and training in different contexts. An exploratory thematic qualitative analysis of inspectors' comments within general Further Education college Ofsted inspection reports was conducted to investigate the balance of control of the learning process between teacher and learner within vocational education and training of young adults in England. A clear difference between outstanding and inadequate provision is reported. Inadequate provision was overwhelmingly teacher-directed. Outstanding provision reflected a collaborative relationship between teacher and learner in directing the learning process, despite the Ofsted framework not explicitly identifying the need for learner involvement in directing the learning process. The present paper offers insight into the understanding of how an effective balance of control of learning between teacher and learner may be realised in vocational education and training settings and highlights the need to consider the modulating role of contextual factors.
\end{abstract}

Keywords: Vocational Education \& Training, Competence, Pedagogy, Further Education, VET and Development

Self-directed learning (SDL) has been conceptualised as a critical workplace competence, but SDL is often not successfully fostered during formal schooling and consequently not fully utilised by many adults during their working life (Kranzow and Hyland 2016; Morrison and Premkumar 2014). Workplace competence refers to an employee's ability to act in order to successfully manage their occupational requirements (Arnold, Nolda, and Nuissl von Rein 2010). In particular, SDL is essential in careers in which there is a demand for employees to manage rapidly changing work environments (Abele and Wiese 2008; Bolhuis and Voeten 2001; Cranton 1992; Morrison and Premkumar 2014).

There is a distinct lack of studies that investigate the extent to which facilitation of self-directed learning is present within vocational education and training (VET) in different contexts. The present research reports upon the balance of control of learning between teacher and learner within VET of young adults studying in Further Education (FE) colleges in England. Balance of control of learning is defined as the relative contribution of teacher and learner in directing the learning process. The theoretical background of SDL and the importance of fostering SDL in VET is reviewed, followed by an overview of VET provision in England, including the role of Ofsted - the government inspection body that sets the standards and objectives for VET provision in England.

\section{Self-directed learning}

\section{The foundations of self-directed learning}

SDL positions with humanistic philosophy and constructivist epistemology. A humanist learning orientation centres on the learner's needs and the possibility for personal growth 
toward self-actualisation (Groen and Kawalilak 2014). The most widely accepted definition (according to Guglielmino, Long, and Hiemstra 2004) of SDL is from Knowles (1975):

In its broadest meaning, "self-directed learning" describes a process in which individuals take the initiative, with or without the help of others, in diagnosing their learning needs, formulating learning goals, identifying human and material resources for learning, choosing and implementing appropriate learning strategies, and evaluating learning outcomes. (18)

SDL is a core theoretical framework in adult education research (Garrison 1992). In 1971, Tough showed that the majority of adult learning is self-directed, representing "major, highly deliberate effort to gain certain knowledge and skill (or to change in some other way)" (1). Knowles $(1970,1975,1980)$ theorised that adults have a deep psychological need to be self-directed and are motivated by knowing why learning particular knowledge or skills may be important to them in their lives.

Knowles (1975) argued that SDL is "a basic human competence - the ability to learn on one's own" (17). But at the same time, he identified that it is a mistake to assume that adults automatically have the necessary skills to be effective self-directed learners. Knowles promoted the facilitation of SDL in formal education, but warned it can be "a very risky venture" (44) and "Students entering into these programs without having learned the skills of self-directed inquiry will experience anxiety, frustration, and often failure, and so will their teachers" (15).

Fostering the skills necessary for SDL has been identified as an important outcome of education (Candy 1991; Cranton 1992). Moore (1972, 80) pointed out that "Most educational theories stipulate the desirability of learners' acquiring sufficient skill in preparation, execution, and evaluation to conduct their own learning." Rogers $(1969,304)$ ma de a convincing argument that facilitation of SDL is the most important goal of formal education: "A way must be found to develop a climate in the system in which the focus is not upon teaching, but the facilitation of self-directed learning."

Models of SDL have highlighted different dimensions of SDL. For instance, Brockett and Hiemstra (1991) emphasised the need to consider personality characteristics of the learner: the desire or preference toward taking responsibility for the learning process. However, when reviewing Brockett and Hiemstra's work, Flannery (1993) pointed out that it is also important to consider that SDL is not possible in all contexts. Rather, the nature of a society at a particular time determines to a large extent the objectives and means of learning (Merriam, Caffarella, and Baumgartner 2012).

Garrison (1997) aimed to develop a more comprehensive model of SDL. He proposed that SDL has three dimensions: motivation (entering/task), self-monitoring (responsibility), and self-management (control). G arrison explained that motivation "plays a very significant role in the initiation and maintenance of effort" (26). Self -monitoring addresses metacognitive and cognitive processes: "monitoring the repertoire of learning strategies as well as an awareness of and an ability to think about our thinking" (24). G arrison theorised that "selfmanagement" within formal education may, paradoxically, rather represent a cooperative process, where "the control over management of learning tasks is realized in a collaborative relationship between teacher and learner" (23). In regard to the balance of control of learning between teacher and learner Garrison explained, "Issues of control must balance educational norms and standards (e.g., what counts as worthwhile knowledge) with student choice and the 
responsibility for constructing personal meaning" (23). To the knowledge of this author, research is lacking that has examined this hypothesis in VET.

\section{The importance of fostering self-directed learning in vocational education and training}

VET is evolving in individual ways in different countries (Bathmaker 2017), but competencybased learning is becoming more commonplace including in the USA and within various European countries (Biemans et al. 2004; Jossberger et al. 2010). For instance, in some VET institutions in the Netherlands "students are given the opportunity to direct their own learning by selecting learning tasks that fit their needs and interests" (Kicken et al. 2009, 439). In these contexts, a portfolio is often used to document learning progress. But at the same time, such programs introduce a problem: learners often do not have the necessary skills for SDL (Jossberger et al. 2010; Kicken et al. 2009). It is clear that students face difficulties with SDL: "when students who are used to a teacher-directed learning environment suddenly enter an educational setting which demands them to direct their own learning, their lack of selfdirected learning skills may impede them in becoming successful independent learners" (Kicken et al. 2009, 440).

Thus, it seems logical that the educator must assist learners to develop the necessary skills for SDL (Jossberger et al. 2010; Kicken et al. 2009). In examining VET programs that actively encourage SDL - a process defined by learner control over both the objectives and means of learning (Mocker and Spear 1982) - it appears that some teacher-direction is preferential (e.g., Jossberger et al. 2010; Kicken et al. 2009). However, to date little research has been conducted that has described an effective balance of control between teacher and learner during the teaching-learning transaction.

There are a number of key benefits of fostering the necessary skills for SDL. SDL is essential for employees to keep updated with knowledge and skills, especially for individuals in complex careers (Dunlap and Grabinger 2003; Oddi 1987). Knowles $(1975,15)$ referred to the "half-life" of facts (or skills), w hich predicts that half of knowledge learned will become obsolete in a particular period of time. Moreover, SDL allows individuals to "upskill" in the event of changes in economic conditions such as labour market shifts, providing the individual with a certain protection against long-term unemployment (Barnes, Brown, and Warhurst 2016). Furthermore, the proactive behaviour associated with SDL is directly associated with long-term career success (Seibert, Kraimer, and Crant 2001). Lucas, Spencer, and Claxton $(2012,9)$ summarise that VET should prioritise the enabling of working competence, which includes fostering the "wider skills for growth: having an inquisitive and resilient attitude towards constant improvement - the 'independent learner'."

\section{Changing educational goals of vocational education and training in England}

On 29 March 2017, in order to commence the process of leaving the European Union, the Prime Minister of the United Kingdom (UK) Theresa May wrote to the President of the European Council Donald Tusk to trigger Article 50 of the treaty on the European Union (May 2017). In preparation for entering a time period of uncertainty, the government initiated a Foresight project exploring the future of skills and lifelong learning in a changing world (Government Office for Science 2016). As part of this project, Barnes, Brown, and Warhurst (2016, 21) explained, "The education and skills system has a vital role to play in equipping individuals with the skills, competencies and attributes necessary to cope and manage with labour market and other shifts over their lifecourse." Tuckett and Field $(2016,4)$ identified the problem that "The combination of an ageing demography, technological change, and 
increased international competition at work, alongside evidence of the wider benefits to health and well-being bestowed by learning, have led to an increased interest in promoting learning throughout adult life." Changes in economic conditions are demanding changes in educational goals. VET is set to play an important role in securing the UK's future economic competitiveness (HM Government 2017).

An important demographic change in England is that adolescents and young adults are remaining in formal education for longer. In 2015, the compulsory "school leaving age" in England was raised to 18 years, which stipulates that persons should remain in full- or parttime education or training up until at least this age (EC 2015). Moreover, the proportion of 16 to 18 year olds in full-time education in England rose by 15 percentage points to $71 \%$ between 1997 and 2015 (UK Parliament 2016).

In the academic year 2016-2017, 744,000 16 to 18 year olds studied in FE colleges in England, in comparison to 433,000 16 to 18 year olds who continued their studies in traditional schools (AoC 2017). For the overwhelming majority of young adults studying in FE colleges in England, qualifications represent a variety of VET at ISCED ${ }^{1}$ level 3 and very few students pursue VET qualifications in England above this level (HM Government 2017). An additional 75,000 16 to 18 year olds undertook an apprenticeship through FE colleges (AoC 2017). 23\% of these FE students were from an ethnic minority background and 17\% had a learning difficulty or disability (AoC 2017).

It is concerning that HM Government (2017) recently reported that VET in England has "fallen behind" in comparison to other VET systems such as in Germany and Norway (37). Moreover, the government summarised that VET provision mostly represents lower level technical qualifications with a broad and generalised curriculum and "The existing system can be complex and confusing, which does not deliver for individuals, for the skills needs of employers, or for the wider economy" (37).

However, in what appears to be a contradiction to these conclusions, Ofsted judged $77 \%$ of FE colleges as "good" or "outstanding" for "overall effectiveness" at their most recent inspection (AoC 2017). Previously, researchers have analysed Ofsted inspection reports to gain insight into various schooling issues such as: management and attendance (Reid 2007); race equality (Osler and Morrison 2002); radicalisation (Mogra 2016); child protection and safeguarding (Craven and Tooley 2016); and resource management (Levačić and Glover 1998). To the knowledge of the present author, no previous study has analysed Ofsted reports in order to gain a systemic understanding of the extent to which teachers and learners assume control of directing the learning process. In the present study, teaching-learning transactions within Ofsted reports were analysed in order to further our understanding of,

- What was the balance of control of the learning process between teacher and learner?

\section{Method}

The methodological approach of this study was an exploratory thematic qualitative analysis of inspectors' comments within general FE college Ofsted inspection reports.

\section{The inspection process}

Triangulation of data collection is used by Ofsted to make judgements presented in inspection reports. During FE college visits data collection includes: "observations of teaching, learning and assessment, as well as support arrangements, discussions with learners, scrutiny of 
learners' work and the arrangements made for them to gain experience of work. Inspectors may undertake some inspection activities jointly with providers' staff, such as visits to learning sessions, to evaluate the progress that learners are making" (Ofsted 2017, 12) . Preinspection analysis is made of institutions' self-assessment and quality improvement plans, performance data, information about the local economic and social context and any additional information such as feedback from parents, carers or employers (Ofsted 2017). Inter-inspector reliability is ensured by the lead inspector who monitors inspections, confirming that inspections are carried out in accordance with the principles of inspection and the ethical code of conduct (Ofsted 2017).

Inspectors make judgements against Ofsted's inspection framework (Ofsted 2017). FE colleges are judged on their "overall effectiveness" of provision, but also on specific aspects such as effectiveness of management and leadership. The present study focussed upon the inspection judgements of "quality of teaching, learning and assessment", which like all other aspects of provision is rated by inspectors as either outstanding, good, requires improvement or inadequate. In the present paper, a comparative analysis was made between teaching, learning and assessment rated as "outstanding" and "inadequate". Ofsted grade descriptors for these corresponding standards are presented in table 1. Inspectors are expected to adopt a "best-fit" approach (Ofsted 2017, 44), but grade descriptors are used as a guidance rather than a "box-ticking" exercise; inspectors are encouraged to utilise their expertise to make judgements (Baxter and Clarke 2013; Ofsted 2017).

\section{Data collection and analysis}

Archival data were retrieved from the UK Government Document Archive Office for Standards in Education in 2017 from all general FE colleges $(n=226)$ in England. The most recent college inspection report from each institution was retrieved. The 226 inspection reports were sorted by "overall effectiveness" into the four possible outcome grade categories defined by Ofsted (2017): inadequate $(n=17)$, requires improvement $(n=54)$, good $(n=123)$, or outstanding $(\mathrm{n}=32)$. A predefined inclusion criteria was that the inspection grading for "quality of teaching, learning and assessment" matched the inspection grading for "overall effectiveness" of the college. Thus, "outstanding" teaching, learning and assessment within "outstanding" institutions (overall effectiveness) was compared and contrasted with "inadequate" teaching, learning and assessment within "inadequate" institutions. From the 17 inadequate institutions, 11 met the inclusion criteria. In order to make a comparative analysis, a random sample $(n=11)$ of outstanding FE college inspection reports, which also met the inclusion criteria, was also subject to analysis.

The analysis of inspectors' comments followed the six phases described by Braun and Clarke (2006). Data analysis software MAXQDA10 was used to code and organise the data. The 22 inspection reports were uploaded in PDF format into the software in order to begin the process of data coding and identifying themes. First, data familiarisation was made where the investigator began to read the inspectors' comments and noted down initial ideas regarding possible codes and themes within the data. Even at the initial stage of analysis, it became clear that inspectors' descriptions of teaching-learning transactions were detailed and provided a rich insight into the balance of control of learning between teacher and learner. At the same time, it should be noted that the Ofsted framework was not considered a fitting frame to examine the research question of the current paper. Given the exploratory nature of the present study, the analysis was thus inductive in the sense that codes and themes were not predetermined, but defined and redefined during the analysis. 
Using the data analysis software, inspection reports were subject to analysis: parts of sentences, whole sentences, and groups of sentences were assigned initial codes such as, "gateway skills", "scenario based", "competencies", "expectations", and "environment". Many were assigned multiple codes. During the progression of the analysis new codes were defined and the initial analysis revisited and data were recoded, where applicable.

During data analysis and organisation of the data, the researcher sought to identify themes in the data. Themes were identified and redefined a number of times during the analysis. Thematic maps were drawn to assist the organisation of themes to their pertaining sub-themes. After completion of the coding stage, the data software program was used to extract a Microsoft Excel (Microsoft Office Professional Plus 2016) data document where data extracts were organised automatically by the software into 2 groups of data (outstanding and inadequate) and by themes and their pertaining sub-themes, which were identified at this stage of the analysis.

Data within this data document were then re-read and parts of the data were highlighted in order to begin the process of identifying representative extracts for the presentation of data. At the same time, further notes were made, which represented short summaries of the thematic content of the extracts. Examples of the notes are: "boring and uninspiring", "well-planned, variety of methods, memorable, meaningful", "not meeting the needs or interests of students", and "peer-feedback, frequent accurate feedback from a number of angles". This process assisted in finalising the themes and sub-themes presented in this report. At times, the data organisation was complicated by the overlapping of data into various categories; the researcher took a "best-fit" approach to the classification of data. But, however, it is important to note that the researcher felt that this reflected the close interaction of the elements of the teaching-learning process that at times were difficult to separate.

A total of 10 sub-themes were identified in the data which represented dimensions of the teaching-learning transaction, which pertained to one of four learning process dimensions: planning learning, undertaking learning, reviewing learning, or entering/task maintenance. Extracts that reflected each sub-theme were taken from the data sets in order to depict common teaching-learning transactional patterns within both outstanding and inadequate provision.

The analytical approach used in this study has a number of advantages including: highlighting similarities and differences between data sets; suitability for informing policy development; and generating unanticipated insights (Braun and Clarke 2006). The latter possibility was of particular importance given the "clear lack of documentation regarding how to promote and actualize SDL" (Morrison and Premkumar 2014, 1) and given that we are today unsure what an education designed for assisting learners to be self-directed may actually look like (Beese and Watson 2016).

Although the present study was exploratory and inductive in nature, it is important to note that "researchers cannot free themselves of their theoretical and epistemological commitments, and data are not coded in an epistemological vacuum" (Braun and Clarke 2006, 84). In this regard, it is necessary to identify that the researcher was familiar with Ofsted inspection processes, had experience of teaching VET within a FE college, had been himself rated as an "outstanding" teacher by Ofsted during a FE college inspection, and was interpreting the data with the foresight of viewing SDL as a process, with the presumption that the current methodology was not designed to examine differences or changes in learner characteristics toward being self-directed.

Ofsted inspection reports are Crown Copyright. Thus, all extracts were quoted verbatim from the 22 Ofsted inspection reports used for analysis. In data presentation, extracts 
from outstanding and inadequate institutions were labelled "Outstanding" (1 to 11) and "Inadequate" (1 to 11), respectively. During the presentation of the findings reference was made to Ofsted FE grade descriptors for quality of teaching, learning and assessment, post hoc of data analysis, in order to draw conclusions in consideration of the Ofsted framework. In this regard, cross reference was made to the nine grade Ofsted descriptors for outstanding teaching, learning and assessment labelled "OGD" (1 to 9) and the seven Ofsted grade descriptors for inadequate teaching, learning and assessment labelled "IGD" (1 to 7), further details of which are presented in table 1 .

\section{Findings}

There was a clear difference between outstanding and inadequate provision upon examination of teaching-learning transactions. In inadequate provision, teachers tended to hold control over directing the learning process. In outstanding provision there was a share of control between teacher and learner. This was in spite of the Ofsted framework, which does not appear to explicitly identify the need for learner involvement in directing the learning process. Data are presented in accordance to the four themes which reflect dimensions of the learning process and their pertaining sub-themes identified during data analysis which reflect dimensions of the teaching-learning transaction. Some of the integral details presented are particularly insightful.

\section{Planning learning}

\section{Goal and target setting}

In outstanding institutions, learners were given teacher guidance about setting aspirational but achievable goals, however learners were encouraged to take a share of control for setting, monitoring, and reviewing goals. It is important to note that learner involvement in directing the planning of learning is not identified by the Ofsted framework, which rather focuses upon the role of the teacher in directing the short- and long-term planning of learning (OGD3, OGD4 and OGD5). 
Learners are curious, interested and keen to learn. They seek out and use new information to develop, consolidate an deepen their knowledge, understanding and skills. They thrive in learning sessions and, where appropriate, use their

experiences in the workplace to further develop their knowledge, skills and understanding.

Learners are eager to know how they can improve their work and develop their knowledge, understanding and skills. They capitalise on opportunities to use feedback to improve. Staff check learners' understanding systematically and effectively, offering clearly directed and timely support that has a notable impact on improving learning.

Staff are determined that learners achieve well. They have excellent subject knowledge and motivate and engage learners, who enjoy the work they complete. Staff have consistently high expectations of all learners' attitudes to learning and learners are set challenging targets to achieve.

Staff plan learning sessions and assessments very effectively so that all learners undertake demanding work that helps them to realise their potential. Staff identify and support any learner who is falling behind and enable almost all to catch

Staff gather a useful range of accurate assessment information and use this to give learners incisive feedback about what they can do to improve their knowledge, understanding and skills. Learners are committed to taking these next steps and their work shows that almost all are making substantial and sustained progress.

Staff set work that consolidates learning, deepens understanding and develops skills, and prepares learners very well for their next steps.

Where appropriate, parents and/or employers are provided with clear and timely information that details the extent of learners' progress in relation to the standards expected and what they need to do to improve.

Staff are quick to challenge stereotypes and the use of derogatory language, including at work. Resources and teaching strategies reflect and value the diversity of learners' experiences and provide learners with a comprehensive understanding of people and communities beyond their immediate experience.

Staff promote, where appropriate, English, mathematics, ICT and employability skills exceptionally well and ensure that learners are well-equipped with the necessary skills to progress to their next steps.
Cross reference

code

The judgement of the quality of teaching, learning and assessment is likely to be inadequate where one or more of the following applies,

OGD1

Teaching and/or assessment is poorly planned.

Weak assessment practice means that teaching fails to meet learners' needs.

Learners or particular groups of learners are making inadequate progress because teaching does not develo their knowledge, understanding and skills sufficiently.

Learners are not developing English, mathematics, ICT or employability skills adequately to equip them for their future progression.

Staff do not promote equality of opportunity or understanding of diversity effectively and this disadvantages individuals or groups of learners.

As a result of weak teaching, learning and assessment over time, learners or groups of learners make insufficient progress and are unsuccessful in attaining their learning goals and progressing to their planned next steps.

Staff lack expertise and the ability to promote learning and learners do not see its relevance to their everyda lives and planned next steps.

Table 1. Ofsted Framework: FE grade descriptors for outstanding (Ofsted 2017, 44) and inadequate (45) teaching, learning and assessment 
They [teachers] skilfully negotiate aspirational targets with learners who fully understand what they must do to reach these. (Outstanding 1)

Students are encouraged to take ownership of their own learning and to set, monitor and review their targets for improvement. (Outstanding 9)

On the contrary, there was no evidence in inadequate institutions of learner involvement in setting and monitoring goals. Expectations of learners were not high enough and teachers often failed to set challenging goals (IGD6). Moreover, it was clear that teachers did not set goals tailored to the learners' individual needs.

Students do not benefit from challenging targets in each of the components of their study programmes. As a result, the progress that most students make relative to their starting point is slow. (Inadequate 1)

As a result of weak planning, too few teachers use information about learners' starting points and, as a result, almost half of learners are working below their expected target grades. (Inadequate 7)

\section{Progression pathways}

Progression pathways may be interpreted as higher order planning of learning. Before starting college, students in outstanding institutions were provided with a choice of qualifications and given thorough advice and guidance, which enabled learners to take control in making an informed decision concerning their preferred qualification course for study and professional pathway.

Initial advice and guidance are extremely thorough and ensure that students are able to make an informed choice of course. (Outstanding 9)

Trainees receive particularly good information, advice and guidance. Careers advice is outstanding. A very high proportion of learners' progress to appropriate HE or employment. (Outstanding 6)

The college pays particularly good attention to the needs expressed by employers. It responds very positively, ensuring learners have opportunities to gain additional qualifications in those skills advocated by employers. (Outstanding 5)

In contrast, there was a lack of support for learners to enable them to make informed decisions regarding their individual progression pathways in inadequate FE colleges. Ofsted acknowledges that collectively such poor planning leads to poor learner progression (IGD6).

Careers advice and guidance are inadequate. Too few learners and apprentices are provided with impartial advice and guidance to support them in making informed and accurate decisions about their next steps in education, employment or training. (Inadequate 11) 
As a result, learners do not receive a tailored programme adapted to their particular needs and starting points, and the majority make inadequate progress. (Inadequate 9)

\section{Undertaking learning}

\section{Classroom control}

In outstanding institutions, it was apparent that teachers organised learning opportunities that aimed to foster the skills for independent learning. The development of such skills were targeted through a range of learning activities which were organised by the teacher. Ofsted's framework identifies the requirement for the teacher to direct learning activities (OGD4), which includes the need for fostering of such "skills" (OGD1 and OGD9).

They develop the ability to work well on their own when studying and problem solving. (Outstanding 4)

Learners are strongly encouraged and supported to take responsibility for their own learning. (Outstanding 11)

In the most effective lessons, students develop good independent learning and research skills. As a result of the enthusiasm and expert direction of teachers, students are interested and motivated, and work well with each other and in group discussions. (Outstanding 4)

Teachers carefully use group work and research activities to develop students' team working and communication skills and to promote independent learning. (Outstanding 9)

On the contrary, in inadequate institutions such learning opportunities were not apparent and reference to teachers organising learning opportunities that aimed to foster skills for independent learning was distinctly absent (refer to IGD3). Rather, "learning" appeared to be teacher-directed.

Teachers tend to dominate lessons and do not provide enough opportunities for students to explore topics or find solutions to problems. (Inadequate 4)

Learners studying level 3 hair and media makeup courses are too dependent on the teacher to provide information and direct them in their practical work. (Inadequate 6)

\section{Structuring learning opportunities}

In outstanding institutions, teachers structured lessons that enabled individualised learning opportunities. Again, Ofsted's framework portrays the role of the teacher as responsible in arranging such learning opportunities (OGD1, OGD4, OGD5 and OGD9). Teachers appeared to provide a framework for learning, but students were given a degree of flexibility and control to individualise their learning. Inspectors identified the importance of access to appropriate resources as an enabling factor in this process. 
Students enjoy and learn quickly from the stretch and challenge provided by the varied and stimulating tasks set by their teachers. (Outstanding 4)

Teachers set imaginative and challenging tasks and assessments that motivate learners to create highly individual portfolios of work. (Outstanding 3)

The college's virtual learning environment and the excellent range of resources in the library are used very well in much of the college to develop and improve independent learning and research skills. (Outstanding 2)

In contrast, teachers within inadequate institutions planned uniform tasks for students. This is linked to poor planning, failing to meet the needs of students, and insufficient progression over time, which is indicative of inadequate provision (IGD1, IGD2 and IGD6). Furthermore, the lack of availability of quality resources was identified as a barrier for learner-directed inquiry.

Teachers do not plan to meet the needs of the wide range of learners' abilities; they teach a 'one-size-fit-all' approach to the whole group of learners, use assessment poorly and place little emphasis on skills development. (Inadequate 6)

Staff have not developed good materials to help their learners continue their learning outside of the classroom. In many cases, they have developed a few resources for the college's virtual learning environment, which is used principally as a repository for the often low-quality presentations teachers use in lessons. Consequently, most learners are unable to make effective use of this resource for independent study. (Inadequate 3)

\section{Knowledge and skills applied to real world settings}

Outstanding institutions had formed strong industrial and community links and learning of knowledge and skills was applied to real world settings (especially work place settings). This is identified by Ofsted as important in VET (OGD1).

They pepper their teaching with industrial comparisons and scenarios, inspiring students to match commercial time restraints, protocols and professional standards. (Outstanding 8)

On the contrary, there was an apparent lack of vocational application of knowledge and skills in inadequate institutions. This is identified by Ofsted as indicative of inadequate provision (IGD7).

They do not relate topics adequately to students' current interests, future jobs or everyday experiences. In these lessons students quickly lose interest, are uninspired and become distracted. (Inadequate 5) 
Learner support was an important theme for enabling effective progression in gaining knowledge, skills, and competencies, which reflected Ofsted's requirement for the need for clear direction and timely support (OGD2 and OGD4).

Students receive outstanding care, guidance and support. The additional support received by some students often proves to be a key factor in their success. (Outstanding 10)

Learners value the coaching and support provided to help them overcome barriers to learning, including the setting of short-term achievable goals for attendance, personal organisation and self-confidence. (Outstanding 2)

In inadequate institutions, there was evidence of some instances of inappropriate support. Specifically, "help" to complete work was provided, rather than providing support to enable students to work independently.

... staff provide too much help and do not focus sufficiently on supporting them to develop the necessary skills to work independently. (Inadequate 5)

\section{Higher order cognitive processes and knowledge dimensions}

In outstanding institutions, teachers enabled students to engage in learning that targeted higher order cognitive processes (e.g., evaluation and creativity) and knowledge dimensions (e.g., procedural and metacognitive knowledge) of learning (Anderson et al. 2001). This is not explicitly demanded by Ofsted, but the framework does refer to the need for students to deepen their knowledge, understanding, and skills (OGD1).

They [learners] also have a thorough understanding of their responsibility to undertake research and use it to develop their thinking and stimulate their creativity. (Outstanding 4)

On intermediate level art and design they [learners] develop very good critical analysis skills. (Outstanding 7)

They [teachers] continually encourage learners very skilfully to reflect, explore and apply new meanings, technical language, knowledge and concepts to their work. (Outstanding 3)

Conversely, it was evident that higher order cognitive processes and knowledge dimensions were not routinely included within learning episodes in inadequate institutions. In this regard, Ofsted refer to insufficient development of knowledge, understanding, and skills (IGD3).

Learners do not reflect on how well they develop their ability to work and learn without help from their teachers, or on what they can do to improve these skills. (Inadequate 9) 
Few teachers ensure that their learners develop their higher level thinking skills and master and apply theory fluently. (Inadequate 6)

\section{Reviewing learning}

\section{Feedback and monitoring}

Effective feedback was highlighted as an important theme for the progression of students by inspectors. In outstanding institutions feedback was threefold: self-assessment, teacherassessment, and peer-assessment. The Ofsted framework highlights the need for effective teacher assessment, but does not refer to the need for self- and peer-assessment (OGD5 and OGD7).

Students are aware of their learning targets and are encouraged to take charge of their own learning and monitor their own progress. (Outstanding 9)

Learners receive positive and helpful feedback from their teachers in lessons and this aids them to progress and improve their work. (Outstanding 3 )

... [Learners] are encouraged to reflect as individuals on future development needs. (Outstanding 8)

... [Learners] make particularly good use of their time and peer-assess finished work. (Outstanding 10)

Finally, students in outstanding institutions also assisted in reviewing the quality of provision.

Learners contribute fully to the development of the curriculum. They participate actively in learner consultation groups. They feel their opinions are valued highly by college staff as their feedback is used to improve the provision. (Outstanding 7)

In comparison, the practice of self- and peer-assessment was distinctly absent in inadequate institutions. Furthermore, inspectors commented upon the lack of quality and timely feedback that was given by teachers to learners, which is also identified by Ofsted as a key factor that leads to insufficient learner progress (IGD6).

Teachers' feedback on learners' assessed work does not provide sufficient detail on how learners can improve their work. Errors in spelling, punctuation and grammar persist in learners' work because these are not systematically corrected by their teachers.

(Inadequate 11)

Learners often continue to make the same basic errors and mistakes within their written work and do not receive the support they need to develop and make progress. (Inadequate 10)

Teachers often provide feedback on learners' written work that is superficial and does not provide the guidance learners need to improve the quality of subsequent work.

(Inadequate 3) 


\section{Entering/task maintenance}

\section{Expectations}

Outstanding institutions had established a "culture" of high expectations, which concurred with the demands of Ofsted for constant high expectations for all learners (OGD3).

The Principal, senior managers and governors have established a culture of high expectations for staff and students alike. (Outstanding 10)

They have an unrelenting determination to ensure learners achieve to their full potential. (Outstanding 3)

Teachers and other staff did not take responsibility for establishing a culture of high expectations in inadequate institutions.

In too many subject areas, teachers' expectations of what learners can achieve are too low. Subsequently, the standard of learners' work is not consistently of a high quality and too often is not of the standard expected by employers. (Inadequate 8)

Senior leaders have allowed the quality of provision to decline to unacceptably low standards. (Inadequate 11)

\section{Inspiring environments}

Finally, in outstanding institutions teachers worked with other staff to establish inspiring learning environments. In this respect, the Ofsted framework identifies the need for learners to be "curious, interested and keen to learn" (OGD1).

Managers, teachers and support staff are extremely effective role models for learners in setting high professional standards and promoting a culture of inclusion, courtesy and respect for each other. (Outstanding 7)

Inspiring learning environments were often not present in inadequate institutions.

In many lessons, learners lose interest and become bored because too many lessons are uninspiring and lack sufficient pace or challenge to motivate learners to attend, work hard and make good progress. (Inadequate 9)

The findings of this report offer a rich insight into the understanding of the balance of control of the learning process between teacher and learner in VET provision of young adults in England (refer to table 2 for a summary). The systemic nature of the present study was a 


\begin{tabular}{|c|c|c|c|c|c|c|c|}
\hline \multirow[b]{2}{*}{$\begin{array}{l}\text { Learning } \\
\text { process } \\
\text { dimension }\end{array}$} & \multirow[b]{2}{*}{$\begin{array}{l}\text { Teaching- } \\
\text { learning } \\
\text { transaction } \\
\text { dimension } \\
\end{array}$} & \multicolumn{2}{|c|}{ Themes in outstanding provision } & \multicolumn{4}{|c|}{ Themes in inadequate provision } \\
\hline & & Teacher & Learner & $\begin{array}{l}* \text { Ofsted } \\
\text { grade } \\
\text { descriptor }\end{array}$ & Teacher & Learner & $\begin{array}{l}* * \text { Ofsted } \\
\text { grade } \\
\text { descriptor }\end{array}$ \\
\hline \multirow[t]{2}{*}{$\begin{array}{l}\text { Planning } \\
\text { learning }\end{array}$} & $\begin{array}{l}\text { Goal and target } \\
\text { setting }\end{array}$ & $\begin{array}{l}\text { Teachers assist and advise in } \\
\text { setting, monitoring, and } \\
\text { reviewing challenging targets. }\end{array}$ & $\begin{array}{l}\text { Enables learners to assume partial control } \\
\text { and responsibility. }\end{array}$ & $\begin{array}{l}\text { OGD3 } \\
\text { OGD4 } \\
\text { OGD5 }\end{array}$ & $\begin{array}{l}\text { Teachers set targets, which are not } \\
\text { always challenging. }\end{array}$ & $\begin{array}{l}\text { Learners often do not assist in } \\
\text { target setting and may not be } \\
\text { challenged. }\end{array}$ & IGD6 \\
\hline & $\begin{array}{l}\text { Progression } \\
\text { pathways }\end{array}$ & $\begin{array}{l}\text { Teachers offer accurate and } \\
\text { individualised guidance about } \\
\text { possible pathways. }\end{array}$ & $\begin{array}{l}\text { Learners are enabled to make informed } \\
\text { guided decisions. }\end{array}$ & & $\begin{array}{l}\text { Teachers may not provide accurate } \\
\text { and individualised guidance about } \\
\text { possible pathways. }\end{array}$ & $\begin{array}{l}\text { Learners may make decisions, but } \\
\text { decisions may not be informed or } \\
\text { appropriately guided. }\end{array}$ & IGD6 \\
\hline \multirow[t]{5}{*}{$\begin{array}{l}\text { Undertaking } \\
\text { learning }\end{array}$} & $\begin{array}{l}\text { Classroom } \\
\text { control }\end{array}$ & $\begin{array}{l}\text { Teachers build student-centred } \\
\text { environments and offer student } \\
\text { control and responsibility. }\end{array}$ & $\begin{array}{l}\text { Enables students to work on individualised } \\
\text { tasks independently or in groups, allowing } \\
\text { the development of competencies } \\
\text { alongside skills and knowledge. Enables } \\
\text { learners to assume more control and } \\
\text { responsibility of progressing in their } \\
\text { learning. }\end{array}$ & $\begin{array}{l}\text { OGD1 } \\
\text { OGD4 } \\
\text { OGD9 }\end{array}$ & $\begin{array}{l}\text { Teachers can dominate in a teacher- } \\
\text { centred environment. Teachers hold } \\
\text { control and responsibility of the } \\
\text { learning process. For instance, } \\
\text { teachers set the pace and methods for } \\
\text { learning. }\end{array}$ & $\begin{array}{l}\text { Learners do not assume control } \\
\text { and responsibility for undertaking } \\
\text { learning. Students become bored, } \\
\text { learning progress is slowed, and } \\
\text { learning is seldom focussed on } \\
\text { the development of competencies. }\end{array}$ & IGD3 \\
\hline & $\begin{array}{l}\text { Structuring } \\
\text { learning } \\
\text { opportunities }\end{array}$ & $\begin{array}{l}\text { Teachers organise } \\
\text { individualised learning } \\
\text { opportunities and resources. }\end{array}$ & $\begin{array}{l}\text { Enables individualised learning of } \\
\text { knowledge, competencies, and skills. }\end{array}$ & $\begin{array}{l}\text { OGD1 } \\
\text { OGD4 } \\
\text { OGD5 } \\
\text { OGD9 }\end{array}$ & $\begin{array}{l}\text { Inflexible uniform learning } \\
\text { experiences are arranged by teachers. }\end{array}$ & Learning is not differentiated. & $\begin{array}{l}\text { IGD1 } \\
\text { IGD2 } \\
\text { IGD6 }\end{array}$ \\
\hline & $\begin{array}{l}\text { Knowledge and } \\
\text { skills applied to } \\
\text { real world } \\
\text { settings }\end{array}$ & $\begin{array}{l}\text { Teachers arrange learning } \\
\text { opportunities that enable } \\
\text { students to apply knowledge } \\
\text { and skills to real world settings } \\
\text { (especially work place } \\
\text { settings). }\end{array}$ & $\begin{array}{l}\text { Enables learners to make individual } \\
\text { meaning of knowledge and skill. }\end{array}$ & OGD1 & $\begin{array}{l}\text { Teaching of core knowledge and skills } \\
\text { do not always provide opportunities } \\
\text { that enable students to apply } \\
\text { knowledge and skills to real world } \\
\text { settings. }\end{array}$ & $\begin{array}{l}\text { Students may not gain an } \\
\text { understanding of why learning of } \\
\text { such knowledge or skills are } \\
\text { important. }\end{array}$ & IGD7 \\
\hline & Learner support & $\begin{array}{l}\text { Teachers ensure appropriate } \\
\text { support for students to enable } \\
\text { continual progress in gaining } \\
\text { knowledge, skills, and } \\
\text { competencies. }\end{array}$ & $\begin{array}{l}\text { Enables learners to overcome barriers to } \\
\text { progression, competence development, } \\
\text { and to assume control and responsibility } \\
\text { for learning. }\end{array}$ & $\begin{array}{l}\text { OGD2 } \\
\text { OGD4 }\end{array}$ & $\begin{array}{l}\text { Support may not always be effective. } \\
\text { Teachers may assist work completion } \\
\text { rather than promoting independent } \\
\text { learning. }\end{array}$ & $\begin{array}{l}\text { Barriers to learner progression } \\
\text { may persist. Students may not } \\
\text { develop competencies to enable } \\
\text { independent learning. }\end{array}$ & \\
\hline & $\begin{array}{l}\text { Higher order } \\
\text { cognitive } \\
\text { processes and } \\
\text { knowledge } \\
\text { dimensions }\end{array}$ & $\begin{array}{l}\text { Teachers stage learning } \\
\text { opportunities that target both } \\
\text { lower and higher order } \\
\text { dimensions of learning. }\end{array}$ & $\begin{array}{l}\text { Students are not confined to rote learning. } \\
\text { They take the opportunity for deep } \\
\text { learning of a topic area and practice higher } \\
\text { order learning processes and dimensions. }\end{array}$ & OGD1 & $\begin{array}{l}\text { Teachers stage learning opportunities } \\
\text { that target mainly lower order } \\
\text { dimensions of learning. }\end{array}$ & $\begin{array}{l}\text { Students are often confined to } \\
\text { rote learning. }\end{array}$ & IGD3 \\
\hline $\begin{array}{l}\text { Reviewing } \\
\text { learning }\end{array}$ & $\begin{array}{l}\text { Feedback and } \\
\text { monitoring }\end{array}$ & $\begin{array}{l}\text { Teachers provide expert } \\
\text { monitoring and feedback and } \\
\text { enable opportunities for self- } \\
\text { and peer-assessment. }\end{array}$ & $\begin{array}{l}\text { Learners are encouraged to reflect upon } \\
\text { progress and perform self- and peer- } \\
\text { assessment. Students are involved in } \\
\text { giving feedback for provision } \\
\text { development. }\end{array}$ & $\begin{array}{l}\text { OGD5 } \\
\text { OGD7 }\end{array}$ & $\begin{array}{l}\text { Teacher feedback is given, but is not } \\
\text { always precise, timely, or appropriate. }\end{array}$ & $\begin{array}{l}\text { Students may not be involved in } \\
\text { feedback and monitoring. } \\
\text { Learners are not appropriately } \\
\text { guided in order to progress } \\
\text { effectively. }\end{array}$ & IGD6 \\
\hline \multirow[t]{2}{*}{$\begin{array}{l}\text { Entering/task } \\
\text { maintenance }\end{array}$} & Expectations & $\begin{array}{l}\text { Teachers set high expectations, } \\
\text { as part of a "culture" of high } \\
\text { expectations. }\end{array}$ & $\begin{array}{l}\text { Learners accept high expectations and are } \\
\text { likely to meet these expectations. }\end{array}$ & OGD3 & $\begin{array}{l}\text { Teachers set expectations, but often } \\
\text { do not demand high expectations. }\end{array}$ & $\begin{array}{l}\text { Learners may not have high } \\
\text { expectations and are likely to } \\
\text { underachieve, or drop out of } \\
\text { college. }\end{array}$ & \\
\hline & $\begin{array}{l}\text { Inspiring } \\
\text { environments }\end{array}$ & $\begin{array}{l}\text { Teachers create inspiring } \\
\text { learning environments. }\end{array}$ & Learners are inspired and motivated. & OGD1 & $\begin{array}{l}\text { Teachers create learning } \\
\text { environments, which may not inspire. }\end{array}$ & $\begin{array}{l}\text { Learners may not be inspired nor } \\
\text { motivated. }\end{array}$ & \\
\hline
\end{tabular}

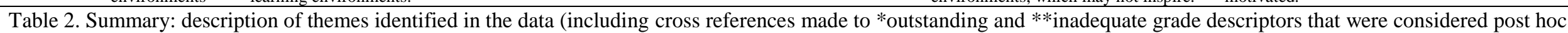
of data analysis (refer to table 1)) 
notable strength, providing an overview of teaching-learning transactions in both outstanding and inadequate VET provision in England. These findings are likely to be interesting and useful for a multitude of stakeholders including: curriculum developers; government policy makers; and VET teachers, managers and support staff, both within England and in other international contexts.

\section{Discussion}

Quite profoundly, inadequate provision in the present study reflected teacher-directed learning where teachers directed the objectives and means of learning (Knowles 1970, 1975, 1980).

Such teaching-learning transactions are reflective of traditional or more didactical approaches (Dewey 1938; Hiemstra 1994). In which, as Freire $(1970,58)$ explained, "Education thus becomes an act of depositing, in which the students are depositories and the teacher is the depositor." This represents a real concern, regarding the small but significant proportion of FE colleges in England to which this conclusion applies. Moreover, this finding was indicative of a recent UK government report which identified that "there is also an issue with the number of young people with weak basic skills who 'churn' through a series of low-level and other qualifications that do not prepare them for further study or employment" (HM Government 2017, 40).

A key finding of this report was that outstanding VET provision in England reflected a "mid-way" between teacher-directed learning and SDL (refer to Knowles 1975, 1980). This balance of control of learning between teacher and learner represented a "collaborative relationship" proposed by Garrison (1997, 23).

This report provides some clues regarding how the skills for SDL may be fostered in VET. For instance, students were encouraged to take ownership for setting goals, but teachers and support staff provided guidance toward setting challenging but achievable goals. During the undertaking of learning, teachers guided learning activities, providing a framework for learning (Arnold 2015). But, at the same time, such tasks enabled a degree of flexibility for students to direct the objectives and means of learning. For example, portfolios were used to facilitate this possibility. Portfolios have been previously identified as "facilitative" for SDL in VET (e.g., Kicken et al. 2009). Furthermore, in the present report it appeared that learner access to quality resources facilitated independent and group research. Additionally, timely and quality support enabled learners to overcome barriers to progressing independently. Moreover, feedback appeared to be a key factor in enabling progression of independent learning. Feedback in outstanding provision was threefold: self-assessment, peer assessment, and teacher assessment.

The ability to apply theory to practice is of particular importance in VET. Thus, as well as the "process" of learning, consideration should be given to the resultant "learning processing" - the cognitive aspect. Garrison (1992) explained, "most conceptualizations of SDL are preoccupied with external control issues, this is an incomplete view of the learning process" (141) . But, "internally self-directedness in terms of constructing meaning is absolute" (141). In this regard, Rogers $(1969,4)$ refers to the type of learning where learners are able to make "personal meaning" of knowledge and skills. This dimension of SDL reflects the constructivist epistemological stance and historical assumptions of SDL (Knowles 1980; Piaget 1964; Tough 1971). In the present study, one important factor that differentiated outstanding provision was the role of teachers in arranging learning opportunities that enabled students to place knowledge or skills in their "real world"; thus, learners were enabled to apply what they were learning to their particular vocation. 
Another imperative finding of this present paper was the hierarchical order of teaching-learning transactions. Historically, the hierarchical order of the process of SDL was not considered (Knowles 1970, 1975, 1980). The importance of higher-order planning of progression pathways was highlighted in this present study. In outstanding institutions, teachers and support staff guided students to make informed choices. Again, such processes fit with the underlying humanistic assumptions of SDL: that every individual has a fitting place in the world; education that is tailored toward enabling self-actualisation is more likely to coincide with learner motivation (Groen and Kawalilak 2014; Maslow 1943, 1954; Rogers 1969).

However, in consideration of the nature of VET in England, there are problems with this basic assumption. Importantly, if all students are directing their progression pathways, collectively, the skill set across a generation may not match the economic demands at that particular time. It is necessary to point out that students' decisions regarding their progression pathway is restricted in England: confined by the qualification offering of FE colleges. In this respect, it should be considered that the UK government recently described the curriculum offering of VET in England as largely "broad" and "generalist" (HM Government 2017, 39) that "does not deliver for individuals, for the skills needs of employers, or for the wider economy" (37). T hese macro level considerations should be taken into account when interpreting this report.

\section{Limitations and suggestions for further research}

The present study had some limitations. The cross-sectional design did not allow insight to the possible fostering of skills for SDL over time (refer to Grow 1991). Longitudinal studies would allow examination of the impact of teaching-learning transactions upon the fostering of skills for SDL. Furthermore, it was not possible to examine individual differences in learner desire or preference toward taking responsibility for SDL (Brockett and Hiemstra 1991). In addition, both the present paper and FE Ofsted framework were systemic and generalisable in nature, whereby teaching, learning and assessment was judged irrespective of the nature of vocation focus or qualification structure. The strength of the present paper is that it provides an overview of the nature of VET in England, in regards to the research question. However, further research examining specific vocation and qualification demands, both within England and in other international contexts, may uncover discrete patterns in the balance of control of learning between teacher and learner.

Moreover, it should be considered that the findings presented in this report were a composition of the interaction of inspectors' perceptions of teaching-learning transactions and interpretation of these judgments was made by a researcher who was an experienced FE college VET teacher. A potential weakness of this present study was the lack of consideration of inter-researcher reliability. Nevertheless, at the same time, the specific professional experience of the researcher likely assisted in making sense of inspectors' comments. But, it is important to consider that the findings presented in this report reflect an interaction of three frames of reference: researcher interpretation of inspectors' interpretations within Ofsted's framework. 


\section{Implications for practice}

The findings of this report example how an effective balance of control of directing the learning process may be realised between teacher and learner in VET. This includes the need to consider the hierarchical order of control issues in regard to directing the objectives of learning. For instance, balancing control of directing progression pathways between learners' interests and economic demands seems imperative in any given VET setting internationally. In addition, the present research identifies the need to consider the modulating effect of contextual factors upon the transactional balance of control of learning between teacher and learner. For instance, the differences discussed in this report between outstanding and inadequate institutions emphasise the impact of the individual institution, including the teacher, in allowing more or less learner self-direction. Moreover, inspectors reported favourably upon teaching-learning transactions where teachers offered students a share of control of directing the learning process. This was in spite of the Ofsted framework that clearly highlights the role of the teacher, but does not appear to explicitly identify the need for learner involvement in directing the learning process - rather, principally reflecting a traditional teacher-directed educational model (Dewey 1938; Freire 1970; Hiemstra 1994; Knowles 1970, 1975, 1980). Considering the crucial role inspection bodies have upon influencing learning culture - which may act to inhibit or promote certain kinds of learning (Hodkinson and James 2003; James and Biesta 2007) - it would appear appropriate that the Ofsted framework is reformed to highlight the importance of facilitating SDL.

In conclusion, the present paper offers insight into the understanding of how an effective balance of control of learning between teacher and learner may be realised in VET settings and highlights the need to consider the modulating role of contextual factors.

Note

1. The International Standard Classification of Education (ISCED) is a statistical framework that categories education into levels from 0 (early childhood) to 8 (doctoral level or equivalent) maintained by the United Nations Educational, Scientific and Cultural Organisation (UNESCO 2012). The most recent version is ISCED 2011.

\section{Acknowledgements}

The author would like to offer his sincere gratitude to Rolf Arnold, Matthias Rohs, Gina Morris, and Leo Morris for their continued support. Special thanks to colleagues that gave fruitful feedback on manuscript drafts, including Dino Cubela, Bastian Steinmüller, and Jessica Neureuther who provided detailed critical comments.

\section{References}

Abele, A. E., and B. S. Wiese. 2008. "The Nomological Network of Self-Management Strategies and Career Success." Journal of Occupational and Organizational Psychology 81 (4): 733-749. doi: 10.1348/096317907X256726

Anderson, L. W., D. R. Krathwohl, P. W. Airasian, K. A. Cruikshank, R. E. Mayer, P.R. Pintrich, J. Raths, and M. C. Wittrock. 2001. A Taxonomy for Learning, Teaching, and Assessing: A Revision of Bloom's Taxonomy of Educational Objectives. New York: Longman. 
AoC (Association of Colleges). 2017. College Key Facts 2016/17. Accessed June 2017. https://indd.adobe.com/view/2ecfd04e-047c-49cc-91d3-18f9bdb9ca73

Arnold, R. 2015. How to Teach Without Instructing: 29 Smart Rules for Educators. Lanham: Rowman and Littlefield.

Arnold, R., S. Nolda, and E. Nuissl von Rein, eds. 2010. Wörterbuch Erwachsenenbildung [Dictionary of Adult Education]. Tübingen: UTB.

Barnes, S-A., A. Brown, and C. Warhurst. 2016. Education as the Underpinning System: Understanding the Propensity for Learning Across the Lifetime. London: Foresight, Government Office for Science. Accessed March 2017. https://www.gov.uk/government/uploads/system/uploads/attachment_data/file/590419/skillslifelong-learning-learning-across-the-lifetime.pdf

Bathmaker, A-M. 2017. "Post-Secondary Education and Training, New Vocational and Hybrid Pathways and Questions of Equity, Inequality and Social Mobility: Introduction to the Special Issue." Journal of Vocational Education and Training 69 (1): 1-9. doi: 10.1080/13636820.2017.1304680

Baxter, J., and J. Clarke. 2013. "Farewell to the Tick Box Inspector? Ofsted and the Changing Regime of School Inspection in England." Oxford Review of Education 39 (5): 702-718. doi: $10.1080 / 03054985.2013 .846852$

Beese, E. B., and S. L. Watson. 2016. "Development of Learner Self-Direction over the Course of a Home Education.” International Journal of Self-Directed Learning 13 (2): 15-37. http://docs.wixstatic.com/ugd/dfdeaf_d36be6e9da1149e0ad02eba380534903.pdf

Biemans, H., L. Nieuwenhuis, R. Poell, M. Mulder, and R. Wesselink. 2004. "Competence-Based VET in the Netherlands: Background and Pitfalls." Journal of Vocational Education and Training 56 (4): 523-538. doi: 10.1080/13636820400200268

Bolhuis, S., and M. M. J. Voeten. 2001. "Toward Self-Directed Learning in Secondary Schools: What do Teachers do?" Teaching and Teacher Education 17 (7): 837-855. doi: 10.1016/S0742051X(01)00034-8

Braun, V., and V. Clarke. 2006. "Using Thematic Analysis in Psychology." Qualitative Research in Psychology 3 (2): 77-101. doi: 10.1191/1478088706qp063oa

Brockett, R. G., and R. Hiemstra. 1991. Self-Direction in Adult Learning: Perspectives on Theory, Research, and Practice. New York: Routledge.

Candy, P. C. 1991. Self-Direction for Lifelong Learning. A Comprehensive Guide to Theory and Practice. San Francisco: Jossey-Bass.

Cranton, P. 1992. Working with Adult Learners. Middletown: Wall \& Emerson.

Craven, B. M., and J. N. Tooley. 2016. "Safeguarding Children: Ofsted and Regulatory Failure." Economic Affairs 36 (1): 64-79. doi: 10.1111/ecaf.12167

Dewey, J. 1938. Experience and Education. New York: Collier Books.

Dunlap, J. C., and S. Grabinger. 2003. "Preparing Students for Lifelong Learning: A Review of Instructional Features and Teaching Methodologies." Performance Improvement Quarterly 16 (2): 6-25. doi: 10.1111/j.1937-8327.2003.tb00276.x

EC (European Commission). 2015. Education and Training Monitor 2015: United Kingdom. Accessed March 2017. http://ec.europa.eu/dgs/education_culture/repository/education/tools /docs/2015/monitor2015-uk_en.pdf

Flannery, D. D. 1993. "Book Review." Review of Book Self-direction in Adult Learning, by R.G. Brockett and R. Hiemstra. Adult Education Quarterly 43 (2): 110-112. doi: 10.1177/0741713693043002005

Freire, P. 1970. Pedagogy of the Oppressed. New York: Continuum.

Garrison, D. R. 1992. "Critical Thinking and Self-Directed Learning in Adult Education: An Analysis of Responsibility and Control Issues." Adult Education Quarterly 42 (3): 136-148. doi: $10.1177 / 074171369204200302$

Garrison, D. R. 1997. "Self-Directed Learning: Toward a Comprehensive Model." Adult Education Quarterly 48 (1): 18-33. doi: 10.1177/074171369704800103 
Government Office for Science. 2016. New Foresight Project to Explore Lifelong Learning. Accessed January 2017. https://www.gov.uk/government/news/new-foresight-project-to-explorelifelong-learning

Groen, J., and C. Kawalilak. 2014. Pathways of Adult Learning: Professional and Education Narratives. Toronto: Canadian Scholars' Press.

Grow, G. O. 1991. "Teaching Learners to be Self-Directed.” Adult Education Quarterly 41 (3): 125149. doi: $10.1177 / 0001848191041003001$

Guglielmino, L. M., H. B. Long, and R. Hiemstra. 2004. "Self-Direction in Learning in the United States." International Journal of Self-Directed Learning 1(1): 1-17. https://docs.wixstatic.com/ugd/dfdeaf_9c5d918f49b8409ebbd25a04f29d25de.pdf

Hiemstra, R. 1994. "Helping Learners Take Responsibility for Self-directed Activities.” In Overcoming Resistance to Self-Direction in Adult Learning: New Directions for Adult and Continuing Education, Edited by R. Hiemstra and R. G. Brockett, 81-87. San Francisco: Jossey-Bass.

HM Government. 2017. Building Our Industrial Strategy. Green Paper. Accessed June 2017. https://www.gov.uk/government/consultations/building-our-industrial-strategy

Hodkinson, P., and D. James. 2003. "Transforming learning cultures in further education." Journal of Vocational Education \& Training 55 (4): 389-406. doi: 10.1080/13636820300200236

James, D., and G. Biesta. 2007. Improving Learning Cultures in Further Education. Routledge: London and New York

Jossberger, H., S. Brand-Gruwel, H. Boshuizen, and M. Van de Wiel. 2010. "The Challenge of SelfDirected and Self-Regulated Learning in Vocational Education: A Theoretical Analysis and Synthesis of Requirements." Journal of Vocational Education and Training 62 (4): 415-440. doi: 10.1080/13636820.2010.523479

Kicken, W., S. Brand-Gruwel, J. J. van Merriënboer, and W. Slot. 2009. "The Effects of PortfolioBased Advice on the Development of Self-Directed Learning Skills in Secondary Vocational Education." Educational Technology Research and Development 57 (4): 439-460. doi: 10.1007/s11423-009-9111-3

Knowles, M. S. 1970. The Modern Practice of Adult Education: Andragogy versus Pedagogy New York: New York Association Press.

Knowles, M. S. 1975. Self-Directed Learning. A Guide for Learners and Teachers. Chicago: Association Press/Follett.

Knowles, M. S. 1980. The Modern Practice of Adult Education (Revised and Updated). New York: Cambridge.

Kranzow, J., and N. Hyland. 2016. "Self-Directed Learning: Developing Readiness in Graduate Students." International Journal of Self-Directed Learning 13(2): 1-14. http://docs.wixstatic.com/ugd/dfdeaf_d36be6e9da1149e0ad02eba380534903.pdf

Levačić, R., and D. Glover. 1998. "Relationship between Efficient Resource Management and School Effectiveness: Evidence from OFSTED Secondary School Inspections." School Effectiveness and School Improvement 9 (1): 95-122. doi: 10.1080/0924345980090105

Lucas, B., E. Spencer, and G. Claxton. 2012. How to Teach Vocational Education: A Theory of Vocational Pedagogy. London: City \& Guilds Centre for Skills Development. http://repository.winchester.ac.uk/82/1/Lucas\%2C\%20Spencer\%20and\%20Claxton\%20\%282 $012 \% 29 \% 20 \mathrm{How} \% 20$ to $\% 20$ teach $\% 20$ vocational\%20education $\% 20 \% 28 \mathrm{VocPed} 1 \% 2 \mathrm{C} \% 20 \mathrm{CG}$ $\% 29 . p d f$

Maslow, A. H. 1943. “A Theory of Human Motivation.” Psychological Review 50(4): 370-396.

Maslow, A. H. 1954. Motivation and Personality. Manhattan: Harper \& Brothers.

May, T. M. 2017. Prime Minister's Letter to European Council President Donald Tusk. Accessed April 2017. https://www.gov.uk/government/uploads/system/uploads/attachment_data/file/604079/Prime_ Ministers_letter_to_European_Council_President_Donald_Tusk.pdf

Merriam, S. B., R. S. Caffarella, and L. M. Baumgartner. 2012. Learning in Adulthood: A Comprehensive Guide. San Francisco: John Wiley \& Sons. 
Mocker, D. W., and G. E Spear. 1982. Lifelong Learning: Formal, Nonformal, Informal and SelfDirected. Columbus: ERIC Clearinghouse on Adult, Career, and Vocational Education. Accessed January 2017. http://files.eric.ed.gov/fulltext/ED220723.pdf

Mogra, I. 2016. "The 'Trojan Horse' Affair and Radicalisation: an Analysis of Ofsted Reports." Educational Review 68 (4): 444-465. doi: 10.1080/00131911.2015.1130027

Moore, M. G. 1972. "Learner Autonomy: The Second Dimension of Independent Learning." Convergence 5 (2): 76-88.

Morrison, D., and K. Premkumar. 2014. "Practical Strategies to Promote Self-Directed Learning in the Medical Curriculum." International Journal of Self-Directed Learning 11(1): 1-11. https://docs.wixstatic.com/ugd/dfdeaf_1989e2278e76458ba77c06aadae54ad1.pdf

Oddi, L. F. 1987. "Perspectives on Self-Directed Learning." Adult Education Quarterly 38 (1): 21-31. doi: 10.1177/0001848187038001003

Ofsted. 2017. Further Education and Skills Inspection Handbook (Revised July 2017). Accessed October 2017. https://www.gov.uk/government/publications/further-education-and-skillsinspection-handbook

Osler, A., and M. Morrison. 2002. "Can Race Equality be Inspected? Challenges for Policy and Practice Raised by the OFSTED School Inspection Framework." British Educational Research Journal 28 (3): 327-338. doi: 10.1080/01411920220137421

Piaget, J. 1964. "Development and Learning." In Piaget Rediscovered, edited by R. E. Ripple \& V. N. Rockcastle, 7-20. New York: Cornell University Press.

Reid, K. 2007. "An Evaluation of OFSTED Reports on LEAs' Management of Attendance Issues." Educational Management Administration \& Leadership 35 (3): 395-413. doi: $10.1177 / 1741143207078181$

Rogers, C. R. 1969. Freedom to Learn. Columbus: Charles Merrill.

Seibert, S. E., M. L. Kraimer, and J. M. Crant. 2001. "What do Proactive People do? A Longitudinal Model Linking Proactive Personality and Career Success." Personnel Psychology 54 (4): 845874. doi: 10.1111/j.1744-6570.2001.tb00234.x

Tough, A. 1971. The Adult's Learning Projects: A Fresh Approach to Theory and Practice in Adult Education. Accessed January 2017. http://ieti.org/tough/books/alp.htm

Tuckett, A., and J. Field. 2016. Factors and Motivations Affecting Attitudes Towards and Propensity to Learn Through the Life Course. Government Office for Science. Accessed February 2017. https://www.gov.uk/government/uploads/system/uploads/attachment_data/file/598461/Skills_ and_lifelong_learning_-_attitudes_to_learning.pdf

UK Parliament. 2016. Participation in Education and Training: 16-18 Year Olds in England: Social Indicators Page. Accessed March 2017. http://researchbriefings.parliament.uk/ResearchBriefing/Summary/SN02628

UNESCO (United Nations Educational, Scientific and Cultural Organization). 2012. International Standard Classification of Education ISCED 2011. UNESCO Institute for Statistics. Accessed January 2018. http://uis.unesco.org/en/topic/international-standard-classification-educationisced 